\title{
Ordvalgenes teologi
}

Tre artikler i dette nummer af Dansk Teologisk Tidskrift viser på forskellig måde og ud fra forskelligt materiale, at valg af ord og terminologi kan være teologisk betydningsfulde og i særlige tilfælde afgørende for traditionsdannelsen. I den første artikel fortsætter Mogens Müller sine studier i Septuangintas betydning for udfoldelsen af nytestamentlig teologi, som begyndte i sidste nummer. I sidste del gennemgår Mogens Müller en række skriftsteder og enkeltord, hvor LXXs græske oversættelse af den hebraiske tekst på afgørende vis har præget dogmedannelsen. De mest kendte eksempel er Matt 1,23 overtagelse af LXXs brug af $\dot{\eta} \pi \alpha \rho \theta \epsilon$ é $0 \varsigma$ for det hebraiske ord, der betyder "den unge kvinde", men det er langt fra det eneste eksempel. Müllers gennemgang understreger LXXs centrale betydning for kristen teologi.

Jesper Tang Nielsens artikel om mytologisk realisme i Nikodemusevangeliet præsenterer dette evangelium, som i dag stort set er gledet ud i glemsel og kun i begrænset omfang behandlet af forskningen, som et stykke ganske interessant kreativt genskrevet bibel. Tang Nielsen lader evangeliet fremstå som et indblik i datidens folkekristendom, hvor man nok har kendt de evangelier, der kanoniseres, men har haft behov for at genskrive dem og ikke mindst tilføje nye personer og begivenheder. Stilen kalder Tang Nielsen prøvende mytologisk realisme, hvor overnaturlige kræfter griber ind i de konkrete begivenheder, som evangeliet føjer til den velkendte Jesus-historie med en særlig interesse for Pilatus' rolle. Artiklen giver et resumé af evangeliets to meget forskellige hovedudgaver, og sætter dem ind i deres historiske og idemæssige sammenhæng.

Det er velkendt af Martin Luther var optaget af ords betydning og gennemslagskraft. Christian Højgaard Jensen bruger en konkret oversættelse fra Luthers hånd, oversættelsen af Zakarias' Bog, og Luthers specifikke ordvalg, som anledning til nogle principielle overvejelser over oversættelsens betydning for og Det Gamle Testamentes rolle i Luthers teologi. Det sker med udgangspunkt i tre væsentlige temaer: frelseshistorie, kristologi og æstetik.

I nummerets sidste artikel giver Jeppe Bach Nikolajsen sit bud på, hvordan der må afstikkes en ny kurs for nordisk folkekirkelig ekklesiologi, der tager alvorligt at den kristne kirke nu befinder sig i et pluralistisk samfund. Det kræver ifølge forfatteren en øget opmærksomhed omkring kirkens faktiske kropslighed, der understreger kirken som en særlig social størrelse, der er bevidst om sin egenart i forhold til det omkringliggende samfund og dermed også en ændring af hidtidig folkekirketænkning. 